Paedagogia Christiana

2/28 (201 I) - ISSN 1505-6872

Włodzimierz Tyburski*

Toruń

\title{
Człowiek - środowisko przyrodnicze w świetle wybranych stanowisk filozoficznych i ekofilozoficznych
}

\author{
Na przyrodę nie można już więcej patrzeć jak na \\ produkt wykorzystania, musi ona we wszystkich \\ formach jej jawienia być doświadczana jako partner \\ H.-G. Gadamer
}

Filozoficzna refleksja nad miejscem człowieka w środowisku przyrodniczym oraz nad relacjami świata ludzkiego i świata przyrody ma swoją długą historię. Pojawiła się nieomal wraz z aktem narodzin filozofii i z większym lub mniejszym nasileniem towarzyszyła jej dziejom. Stanowiła integralną część filozofii przyrody, której tradycyjny przedmiot zainteresowań koncentrował się na bogatym katalogu zagadnień o charakterze kategorialnym i ontologicznym, z tak fundamentalnymi dla niej zagadnieniami jak: problematyka materii, czasu, przestrzeni, przyczynowości, przyrody ożywionej i nieożywionej oraz wieloma innymi. Z czasem tematykę tę zaczęły podejmować wyłaniające się z filozofii nauki przyrodnicze: biologia, medycyna. $\mathrm{W}$ ostatnich dwóch stuleciach zagadnienie związków człowieka z przyrodą stało się również przedmiotem badań różnych dyscyplin lokujących się na pograniczu wiedzy przyrodniczej i społecznej. Analizą owych związków dokonywaną już nie tyle w wymiarze ogólnym, filozoficznym, ale z wyraźnie

* Prof. zw. dr hab. Włodzimierz Tyburski, kierownik Zakładu Bioetyki i Filozofii Moralnej w Instytucie Filozofii Uniwersytetu Mikołaja Kopernika w Toruniu, członek Komitetu Nauk Filozoficznych Polskiej Akademii Nauk. 
zarysowanych perspektyw teoretycznych i problemowych zajmują się takie dyscypliny, jak: ekologia, etnologia, socjobiologia czy sozologia. Zupełnie nieodległą historią, nieprzekraczającą horyzontu czasowego ostatnich kilkudziesięcioleci legitymuje się ekofilozofia (filozofia ekologiczna), której przedmiot zainteresowań skoncentrowany jest wyłącznie na wieloaspektowych dociekaniach nad związkami człowieka ze środowiskiem przyrodniczym w świetle dokonujących się przemian cywilizacyjnych. Ekofilozofia nawiązuje do dorobku filozofii przyrody $\mathrm{i}$ - wyraźnie to podkreślając - nauk przyrodniczych, ale formułowanym katalogiem problemów, pytań i odpowiedzi klarownie określa właściwy jej tylko przedmiot zainteresowań i specyfikę. Podkreślić należy, że swoistość tej dyscypliny związana jest z przełomem, który, za jej sprawą, określa nową perspektywę postrzegania miejsca człowieka w świecie przyrody i nowym myśleniu o człowieku i przyrodzie w ich wzajemnych związkach. Specyfika i nowość perspektywy badania środowiska przyrodniczego określona jest faktem doświadczanego przez to środowisko kryzysu ekologicznego. Klasyczna filozofia przyrody koncentruje się na świecie przyrody pojętym niejako ahistorycznie i autonomicznie wobec dziejących się wydarzeń kulturowo-cywilizacyjnych i dotyczy świata niezmienionego działalnością człowieka, w tym też sensie jest autonomicznym obiektem dociekań. Nowa dziedzina odnosi się do świata przyrody zmienianego cywilizacyjnie i wyraźnie naznaczonego wpływami i interwencją człowieka. Środowisko przyrodnicze staje się tematem nowej refleksji filozoficznej właśnie z powodu kryzysu tego środowiska. Inaczej aniżeli tradycyjna filozofia przyrody ekofilozofia jest dziedziną refleksji wyrosłą w naszych czasach, gdyż pojawiła się jako refleks dramatycznego i najtrudniejszego do przezwyciężenia problemu współczesności, jakim jest lawinowo już dziś narastający proces degradacji i wyniszczania środowiska przyrodniczego. W obliczu tej granicznej dla losów człowieka i jego przyrodniczego otoczenia sytuacji ze szczególną intensywnością staje, nie po raz pierwszy przecież formułowane, pytanie o sposób istnienia człowieka w przyrodzie, i w konsekwencji o to, jak powinien zachować się wobec swego przyrodniczego otoczenia i dlaczego powinien tak postępować?

W niniejszej wypowiedzi pragnę przedstawić wymienione wyżej dwie perspektywy oglądu i analizy relacji człowiek-środowisko przyrodnicze: filozoficzną i ekofilozoficzną, aby ukazać ich swoistość, odmienności, ale i wspólnotowy wymiar myślenia (tam, gdzie się on wyraźnie uwydatnia) na temat miejsca człowieka w środowisku przyrodniczym i jego stosunku do przyrody, ale także wskazać na filozoficzne źródła współczesnego myślenia ekologicznego. 


\section{Człowiek a środowisko przyrodnicze w refleksji filozoficznej}

Zwracając się ku odległej przeszłości wskażmy, że zagadnienie stosunku człowieka do przyrody szczególnych znaczeń i interpretacji nabierało już w perspektywie kultury i filozofii grecko-rzymskiej. W mitach, eposach homeryckich a później w poematach Hezjoda odnajdujemy idee szacunku dla wszystkich istot składających się na świat natury. Wyłania się z nich wizja rzeczywistości jako organicznej całości, gdzie każda z jej części składowych: bóg, człowiek, zwierzę, roślina, życie organiczne i to, co nieorganiczne, zajmuje właściwe sobie miejsce. Świat jest harmonijną całością, każdy element jest doskonale w ową harmonię wkomponowany, a człowiek podlega takim samym regułom, jakim podlegają wszystkie elementy świata, wszystko zaś przenika życiodajna moc.

Ważne znaczenie dla Greków miał mit o Dionizosie, któremu Zeus powierzył opiekę nad zwierzętami, ptakami, owadami i roślinami i zalecił czuwanie nad nieprzemijalnością i bujnością życia. I choć sam Dionizos doświadczał wielu dramatycznych kolei losu, to zawsze w świadomości Greków symbolizował istotę życia, jego dynamikę i rozwój, oraz potrzebę zachowania i ochrony wszelkich jego form. Dla umysłu greckiego tego okresu nie było ostrego podziału na świat ludzki i podporządkowany mu świat przyrody. Ten ostatni Grecy uważali za swój dom, siedlisko, traktując siebie jako integralną cząstkę tej rzeczywistości, naturę zaś jako sobie pokrewną.

Dla pierwszych greckich filozofów, wywodzących się ze szkoły jońskiej, człowiek jest tylko elementem phỳsis, stanowiąc naturalną, nieodłączną jej część składową. Łączą go ze światem przyrody te same funkcje i procesy. Nie może być inaczej, gdyż człowiek i kosmos składają się z tego samego tworzywa oraz podlegają takim samym regułom.

W pitagorejskim obrazie świata idea związku jedności z wielością przybrała szczególnie wyrazistą postać. Filozoficzna szkoła pitagorejska głosiła ideę świata kosmosu, w którym panują ład, harmonia, doskonałość, piękno. Człowiek jest tu integralną częścią harmonijnej struktury świata. Winien on odkrywać piękno i harmonię świata, poznawać jego doskonały ład, gdyż w ten sposób otrzymuje wskazania, wedle których ma on kierować swoim życiem. Zrozumienie ładu i harmonii świata jest konieczne, gdyż człowiek targany namiętnościami i nieświadomy praw rzeczywistości może być jedynym elementem świata, który zdolny jest jego ład i harmonię zakłócić.

W nurcie podobnego sposobu myślenia znajduje się również filozoficzna szkoła cyników. Jej reprezentanci podkreślali organiczny związek świata ludzkiego i przyrodniczego. Jak twierdzili, człowiek, pragnąc osiągnąć szczęście, powinien ograniczyć swe potrzeby do wymogów natury. Sama 
bowiem natura jest najlepszym nauczycielem tego, jak być powinno. Etyka cyników wyraźnie akcentowała wartość świata przyrodniczego. Jest naturalistyczna $\mathrm{w}$ tym sensie, iż ogłasza priorytet przyrody, upatrując ideał szczęśliwego życia w świecie maksymalnie zbliżonym do natury. W zgodzie $\mathrm{z}$ tym przekonaniem cynicy odrzucali to wszystko, co w dziedzinie potrzeb wykraczało i lokowało się ponad sferą natury i panujących w niej zasad.

Odmiennie sytuuje się myśl Platona (427-347 p.n.e). Istnieje świat przemijających, określonych w czasie, zmysłowych fenomenów, materialnych, przyrodniczych kreacji, ponad którym lokuje się byt prawdziwy - niematerialnych, doskonałych, wiecznych i niezmiennych, posiadających pełnię idei. Jako istoty cielesne, przynależymy do świata organicznych i zmiennych przedmiotów. Ale posiadając nieśmiertelną duszę i rozum transcendujemy do innego porządku, do rzeczywistości idei. Ten świat odciska się w materialnym tworzywie, którego poszczególne zjawiska i fakty są jedynie refleksem, cieniem i pozorem tego, co idealne i doskonałe w swoim prawzorze. Dlatego błąd popełnia ten, kto przywiązuje się do świata rzeczy zmysłowych. Platon nawołuje do tego, ,„aby całą duszą odwrócić się od świata zjawisk, które powstają i giną, a skierować się do bytu rzeczywistego, stałego niezmiennego". Niedoskonały, ulegający przemianom świat przyrodniczy, podzielając status całej rzeczywistości zmysłowej, zostaje w tej filozofii ulokowany na miejscu nieporównanie niższym aniżeli byt wiecznych, doskonałych, posiadających samoistną egzystencję idei.

Arystoteles (384-322 p.n.e.) zakwestionował Platoński podział na rzeczywistość idealną i świat materialnych kreacji. Twierdził, że idee nie mogą samodzielnie egzystować poza realnymi rzeczami, gdyż istnieją tylko konkretne zespoły materii i formy. Jednocześnie konstruował hierarchię bytów, od najprostszych postaci materii poczynając a kończąc na pojęciu czystej formy, dowodząc, że $w$ różnicach trzeba szukać przyczyny każdej rzeczy. Człowiek ma tu pozycję wyróżnioną, co więcej, jako posiadacz duszy ludzkiej ma zdecydowaną przewagę nad światem innych istot ożywionych.

W refleksji nad wyrosłymi w dobie antyku wyobrażeniami świata natury i człowieka nie sposób pominąć wpływowej i żywotnej, gdyż kilka wieków trwającej, filozoficznej szkoły stoików, która była jakby pomostem trwale łączącym kulturę grecka i rzymską. Świat widziany oczyma stoików to jedna wielka, harmonijna całość, żywy i rozumny organizm. Wszystkie jego elementy: ziemia, powietrze, woda, rośliny, zwierzęta i wreszcie sam człowiek tworzą współzależną całość i są w swych funkcjach niezbędne dla pozostałych. Ten świat jest taki, jaki być powinien; przeniknięty ożywiającą go esencją (pneùma - tchnienie) - owym źródłem wszelkiego życia i jego jedności, istnieje i rozwija się w sposób konieczny i celowy. Człowiek jest jego immanentną częścią, poddaną ogólnym regułom istnienia. Jego zadaniem 
jest poznanie ładu świata i dostosowanie się do powszechnej jego harmonii. Dla stoików życie cnotliwe oznaczało życie i działanie zgodne z naturą, jej rytmem i harmonią. To jakby pierwsza z zasad etyki stoickiej. Ze szczególną mocą akcentowała organiczną jedność człowieka z kosmosem oraz cnoty człowieka z prawami natury. Należy spoglądać na siebie - przekonywał Epiktet - ,jako na człowieka będącego cząstką całości”. Filozofia stoicka, kreując - posługując się dzisiejszą terminologią - holistyczną wizję świata, dobrze wpisuje się w katalog filozoficznych tradycji współczesnego myślenia ekologicznego.

Doba średniowiecza przyniosła dramatyczny odwrót od idei głoszonych przez filozoficzne szkoły greckie. Nowa filozofia natury była budowana już na innych zasadach. Przeważać zaczyna przekonanie o wyjątkowym miejscu człowieka. Stawał on ponad naturą, a nawet przeciw niej. Nastąpił wyraźny rozbrat z wcześniej głoszoną ideą komplementarności różnych form życia, mówiącą o tym, że człowiek jest także cząstką uniwersalnego układu. Niejako na uboczu dominującego w myśli średniowiecza stanowiska pojawił się pogląd, w którym odżyły dawne idee, choć pozbawione swego filozoficznego retuszu. Jego twórcą był św. Franciszek z Asyżu (1181-1226), głoszący potrzebę ochrony całego świata przyrody, w tym również przyrody nieożywionej. Zwierzęta nazywał swoimi braćmi i siostrami. Jego kazania do ptaków oraz opowieść o wilku z Gubbio zachwycają poetyckim pięknem, konstrukcją wywodów oraz zdumiewają zakodowaną w nich świetną intuicją ekologiczną. We wskazaniach kierowanych do braci zakonnych swej reguły zalecał działania, w których wyrażać się miała postawa szacunku i miłości dla przyrody, idea ochrony i zachowania jej naturalnych walorów. Jakże głęboki sens ekologiczny miały jego zalecenia, aby w ogrodach pozostawić „nietykalny” ugór, „aby tam mogły bujać zielska i barwić się kwiaty”. „W swą przestrzeń braterstwa włącza całą przyrodę. [...] Braterską więź Franciszka ze światem przyrody można nazwać serdeczną przyjaźnią zakładającą wzajemną życzliwość, zaufanie i pomoc". Jego system etyczny „wykracza poza tradycyjny obszar moralności, ograniczający się do człowieka i stosunków międzyludzkich, i obejmuje relacje człowieka ze światem roślin, zwierząt, a nawet całych ekosystemów"'. U św. Franciszka pojawiła się myśl o nieomal sakramentalnym wymiarze natury, którą później spotykamy w wypowiedziach św. Jana od Krzyża. Do poglądów św. Franciszka z Asyżu nawiązywał także św. Antoni z Padwy, głosząc ideę zbratania ze

${ }^{1}$ S. Jaromi, Inspiracje franciszkańskie w ekologii i ekofilozofii, w: J. Czartoszewski (red.), Nauki humanistyczne i sozologia. Księga pamiatkowa dedykowana księdzu profesorowi Józefowi M. Dołędze, Warszawa 2010, s. 153. 
światem istot żywych, z całą przyrodą, oraz św. Jan Złotousty, który zalecał wszelka wobec zwierzat ludzkość i łagodność.

Poglądy myślicieli epoki odrodzenia określała idea skrajnego antropocentryzmu. Zainteresowanie przyrodą miało dla nich głównie znaczenie utylitarno-poznawcze. Dowodzono - jak czynił to Francis Bacon (1561-1626) - że człowiek po to został stworzony, aby opanować świat natury i podporządkować go sobie. Przekonywał, że ,wiedza i potęga ludzka to jedno i to samo, gdyż nieznajomość przyczyny pozbawia nas skutku. Nie można bowiem przyrody zwyciężyć inaczej niż przez to, że się jej słucha"2. I dodawał: „Panowanie [...] człowieka nad przyrodą opiera się jedynie na kunsztach i naukach"'s. Słusznie zwrócono uwagę na to, że w Novum Organum „zawiera się implicite zasada, że każde działanie wobec przyrody jest moralnie dopuszczalne, jeśli nie szkodzi działającej jednostce bądź innym ludziom bezpośrednio lub $\mathrm{w}$ dającej się przewidzieć perspektywie, a przynosi jakiś pożytek"4. W kilkadziesiąt lat później to stanowisko rozwinięcie i teoretyczne uzasadnienie znalazło w tym sposobie myślenia o świecie, któremu nadano miano kartezjańsko-newtonowskiego paradygmatu.

Przeciwko nurtowi dominacji i dyktatu człowieka wobec natury występował w owych czasach Michel de Montaigne (1533-1593). Nieprawdą jest - twierdził - że świat jest stworzony jedynie dla ludzi, istot myślących. Przecież wszyscy zamieszkujący Ziemię są dziećmi tej samej matki natury. To, że człowiek tak zdecydowanie pragnie odróżnić się od innych stworzeń i podporządkować je swojemu bezwzględnemu panowaniu, jest jedynie wyrazem jego próżności, zarozumialstwa i głupoty. Powinniśmy uznać - przekonywał filozof - że świat istniejący wokół nas posiada wartość, autonomię, wewnętrzną logikę i porządek. Te fakty należy respektować i poważać. Montaigne gloryfikuje świat natury i w konsekwencji dochodzi do wniosku, że życie wedle jego praw jest najbardziej słusznym kierunkiem zachowań i działań człowieka. Żarliwie bronił zwierząt, chwaląc ich liczne zalety: przyjaźń, rozumność, wierność, jednocześnie zdecydowanie sprzeciwiając się wygłaszanym na ich temat krzywdzącym opiniom. Należy wyzbyć się naszych uprzedzeń wobec zwierząt, a tym łatwiej przyjdzie nam to uczynić, gdy uświadomimy sobie, że z tym światem wszystko nas łączy i pod wieloma względami upodabnia. Bywa - powiada Montaigne - że „większa zachodzi różnica między człowiekiem a człowiekiem, niż zwierzę-

2 F. Bacon, Novum Organum, Warszawa 1955, s. 57.

3 Tamże, s. 159.

${ }^{4}$ J. Kopania, Ekologia Kartezjańska. Wprowadzenie do problemu, w: J. Janeczek (red.), Oblicza filozofii XVII wieku, Lublin 2008, s. 374. 
ciem a niektórym człowiekiem" ". Filozof uważa, że ludzie mają określone obowiązki wobec zwierząt (nazywa je współbraćmi i kompanami), a nawet wobec roślin. W esejach O okrucieństwie i Apologia Rajmunda Sebond zawarty jest gorący manifest w obronie świata zwierząt i jego wartości. Próbie waloryzacji świata natury towarzyszy zdecydowana krytyka cywilizacji. To ona właśnie rodzi wszelakie postaci zła. Liczne nieuzasadnione, fałszywe poglądy oraz przesądy i uprzedzenia biorą się także stąd, że człowiek czyni zły użytek ze swego rozumu, czego oczywistym przykładem jest całkowite negowanie wartości świata natury.

Przypominamy nieco obszerniej poglądy Montaigne’a, gdyż wyrażają one, po raz pierwszy chyba w dobie nowożytnej, tak zdecydowany protest przeciwko bezwzględnemu wykorzystaniu zwierząt przez ludzi, a także dlatego, że podejmując próbę waloryzacji natury tak jednoznacznie i dobitnie ogłaszają sprzeciw wobec idei separacji świata ludzkiego i przyrodniczego.

Zwolennikiem solidarności natury i człowieka był także wielki wizjoner owych czasów Tomasz Campanella (1568-1639). W znanej utopii zatytułowanej Miasto słońca rysuje obraz społeczeństwa bytującego w pełnej harmonii z naturą. Społeczeństwo jest tu częścią natury. Żyje zgodnie z prawami i rytmem przyrody, dążąc do ich poznania i zrozumienia, aby podporządkowując się im czerpać siły do rozumnej egzystencji. Jest to egzystencja współuczestnicząca w życiu przyrody. Społeczeństwo to poszukuje oczywiście dróg i możliwości rozwoju, ale nie przez eksploatację i wykorzystanie świata natury, lecz przez świadome poszukiwanie i stosowanie w praktyce harmonijnych, organicznych form kooperacji z przyrodą. Szkicując wizję świata, w którym panuje solidarność całego życia, harmonijne współistnienie człowieka i natury, Campanella antycypuje te współczesne poszukiwania modeli życia społecznego, które spełniałyby zarówno wymogi ekonomii i środowiska naturalnego, brałyby pod uwagę potrzeby człowieka, ale i immanentne dobro przyrody.

Paradygmat antropocentryczny najbardziej wyrazistą postać znalazł w systemie filozofii kartezjańskiej, w którym świat podzielony został na dwie niezależne i niesprowadzalne do siebie substancje: rzecz myślącą (res cogitans) i rzecz rozciągłą (res ekstensa). Radykalny dualizm stał się dla Kartezjusza (1596-1650) uzasadnieniem dla skonstruowania mechanistycznej koncepcji przyrody, wedle której świat materialny jest tylko maszyną pozbawioną celu i świadomości, podległą prawom mechaniki, zaś zadaniem człowieka jest ich poznanie, aby dzięki posiadanej wiedzy podporządkować sobie przyrodę i wykorzystać do własnych celów, gdyż - jak powiada Kartezjusz - po to jesteśmy, aby być ,panami i posiadaczami natury”.

${ }^{5}$ M. de Montaigne, Próby. Apologia Rajmunda Sebond, t. II, Warszawa 1985, s. 152. 
W kartezjańskim pojmowaniu rzeczywistości przyroda pozbawiona została wszelkich symboli i znamion, które w przeszłości przypisywały jej różne kultury i religie. Wszak wyobrażano ją sobie jako żywy organizm, uważano za źródło wszelkiego życia, antropomorfizując nazywano matką karmicielką, żywicielką, a poszczególne części składowe - braćmi i siostrami. Bywało, że nadawano jej sens zgoła metafizyczny. Mechanistyczna interpretacja przyrody pozbawiła ją owych atrybutów i w tym sensie zubożyła obraz świata, choć jednocześnie uczyniła ten świat bardziej przejrzystym dla poznania naukowego i możliwym do technicznego opanowania i podporządkowania. Światopogląd mechanistyczny, odbierając przyrodzie mitologiczny wymiar i desakralizując ją, pozbawił również człowieka tych hamulców i ograniczeń, które wnosiły kultura, normy etyczne, religia, magia, powodując, iż w konsekwencji stosunek człowieka do przyrody wyrażał się jedynie w kategoriach poznawczych i utylitarnych. Wobec świata pojmowanego jako maszyna, rzecz, przedmiot, wszelkie odniesienia metafizyczne, religijne, magiczne i etyczne traciły swój pierwotny sens. Wedle wskazań nowego myślenia, aby dowiedzieć się, na jakich zasadach owa maszyna funkcjonuje, wystarczyło sięgnąć do mechaniki Newtona. To między innymi tam znajdowano uzasadnienie i kwintesencję tego sposobu oglądu i interpretacji świata, któremu z czasem nadano miano kartezjańsko-newtonowskiego paradygmatu ${ }^{6}$. Jego upowszechnienie w następnych stuleciach wpłynęło na zmianę stosunku człowieka wobec świata przyrody. Z postawy w mniejszym lub większym zakresie symbiotyczno-kooperującej zmienia się na postawę dominującą i zarazem panującą, a wraz z nią przekonanie, że świat przyrody po to tylko istnieje, aby stwarzać człowiekowi możliwości rozwoju i budowania własnego świata. Takie przekonanie właściwe jest procesowi budowania cywilizacji zachodniej, któremu towarzyszyło zjawisko fizycznego i psychicznego alienowania się człowieka z jego naturalnego otoczenia, traktowanego jako materiał, tworzywo, z którego konstruował wedle własnego pomysłu i przekonania swój własny świat. Nietrudno zauważyć, że dzieje nowożytnej cywilizacji analizowane z tego punktu widzenia są historią coraz głębiej zarysowującego się podziału rzeczywistości na świat sztuczny, techniczny, wykreowany przez człowieka - w perspektywie jedyny i świat zastany, naturalny, ale oddalający się w przeszłość. Takiemu dychotomicznemu rozdziałowi świata towarzyszyła określona antropologia i aksjologia. „Fundamentalnym założeniem tej antropologii - jak zauważa Zdzisława Pią-

${ }^{6}$ Propozycję odmiennej interpretacji filozofii kartezjańskiej przedstawia J. Kopania, dochodząc do wniosku, że może ona nawet „stać się punktem wyjścia budowania etyki ekologicznej, która pozostawać będzie w zgodności z ludzką potrzebą badania świata i biologiczną koniecznością korzystania z zasobów przyrody: patrz J. Kopania, dz. cyt., s. 375. 
tek - było twierdzenie, że wszystko, co specyficznie ludzkie, czyli Rozum, nie przynależy do świata Przyrody, lecz do inteligibilnego świata rozumu całkowicie niezależnego od zmysłowości i przyrodniczych ograniczeń" i ten tylko jedynie świat, odseperowany od tego, co przyrodnicze i cielesne, jest godnym przedmiotem refleksji filozoficznej ${ }^{7}$. W takiej zaś sytuacji pojawia się niepozbawione pychy i arogancji przekonanie, że porządek ustanowiony przez człowieka jest bardziej godny zaufania i skuteczniejszy aniżeli porządek istniejący z natury i, co za tym idzie, przeświadczenie o możliwości zbudowania świata ludzkiego autonomizującego się od konieczności przyrodniczych i nieliczącego się z wydolnością środowiska.

Podobny jak i Kartezjusza ton pobrzmiewa w wypowiedziach większości wybitnych ludzi tej doby. Sławią oni człowieka jako władcę przyrody, bezwzględnie podporządkowującego sobie całą dostępną mu rzeczywistość. Kryterium postępu upatrują $\mathrm{w}$ procesie izolowania się od świata przyrodniczego, zrywania naturalnych więzów, gdyż - posługując się współczesną terminologią - biosfera jest tu tylko tworzywem, z którego buduje się świat antroposfery.

Poza ludźmi - powiada Spinoza (1632-1677), wpisując się w powyższą koncepcję i argumentację - nie znamy w naturze nic takiego poszczególnego, czego umysłem moglibyśmy się cieszyć i co moglibyśmy zjednać sobie przyjaźnią albo jakimś sposobem obcowania. Dlatego wzgląd na nasz pożytek nie wymaga zachowania niczego $\mathrm{z}$ tego, co jest dane w naturze poza ludźmi, lecz uczy nas zachowania, niszczenia, albo obracania w jakikolwiek sposób na swój użytek tego wszystkiego stosownie do rozmaitej użyteczności ${ }^{8}$.

W dobie oświecenia na plan pierwszy wybijają się poglądy Jana Jakuba Rousseau (1712-1778). Autor Umowy społecznej entuzjastycznie głosił idee powrotu do natury, którą wszakże można odczytać jako następstwo potępienia cywilizacji i przesytu kulturą. Rousseau sławił naturę, pojmowaną jako stan pierwotny. To entuzjastyczne zwrócenie się ku przyrodzie, tęsknota ku prostym naturalnym stosunkom, idealizowanie tego, co nieskażone cywilizacją, przyczyniło się do określenia filozofa jako prekursora idei ekologicznych. Że Rousseau zasłużył sobie na to miano, o tym świadczą jego przestrogi, jakie czynił w związku z niszczeniem środowiska przyrodniczego na skutek żywiołowej i nieracjonalnej eksploatacji. Niepokoiły go zwłaszcza niekorzystne efekty masowego wycinania lasu i degradacja gleby. W związku z tym dowodził, że pustynnienie wielkich obszarów jest naj-

\footnotetext{
7 Z. Piątek, Ekofilozofia, Kraków 2008, s. 123.

${ }^{8}$ B. Spinoza, Etyka, cz. IV, Warszawa 1991, s. 180.
} 
bardziej rzucającym się w oczy skutkiem takiego właśnie barbarzyńskiego gospodarowania zasobami przyrody.

Pod koniec XVII wieku pojawiła się także koncepcja, którą można zaliczyć do tych tworzących genealogię współczesnego humanizmu ekologicznego ${ }^{9}$. Jej autorem był filozof i moralista angielski Jeremy Bentham (1748-1832). Był gorącym orędownikiem idei praw dla zwierząt i uzasadniał, że zasadniczym podobieństwem łączącym je z ludźmi jest odczuwanie cierpień. Bez względu na to, czym się różnimy - przekonywał - wszyscy jesteśmy zdolni do cierpienia. Uważał, że „,nadejdzie czas, kiedy ludzkość weźmie pod opiekę wszystko, co oddycha"".

Temat człowiek a świat przyrody niejednokrotnie pojawia się w myśli filozoficznej doby romantyzmu. Zastanawiano się nad miejscem człowieka w świecie przyrody i analizowano możliwe jego relacje ze środowiskiem naturalnym. Romantycy uczyli rozumieć przyrodę, ale jednocześnie dowodzili, że decydującą instancją poznawczą jest nie tyle rozum, co uczucie. Nie potrafi zrozumieć sensu przyrody ten, kto nie jest w stanie nawiązać z nią uczuciowego kontaktu, kto nie potrafi się w nią wczuć i emocjonalnie z nią związać. To właśnie dzięki uczuciu, sympatii i szacunkowi tworzy się szczególny język, za pomocą którego człowiek nawiązuje kontakt i przymierze z przyrodą, a nawet całym universum. O możliwości nawiązania intymnego dialogu ze światem przyrody, uchwycenia jej rytmu, potrzebie wtopienia się w jej harmonijną całość pisali Schelling, Hölderlin, Novalis, Schleiermacher. Odnaleźć ją można w pismach filozofów niemieckiego romantyzmu, lecz w najbardziej wyrazisty sposób ujawnia się w poglądach F. W. J. Schellinga (1775-1854) na temat przyrody, człowieka i możliwych między nimi relacji. W schelligiańskiej filozofii przyrody naturę charakteryzuje dynamizm, nieustanna zmienność, ewolucyjność i kreatywna moc. Człowiek zaś odzyskuje utraconą niegdyś pierwotną jedność ze światem przyrody. W filozofii niemieckiego romantyka dokonuje się przezwyciężenie separacji „między światem przyrody a człowiekiem jako organizmem", separacji właściwej „matematycznemu przyrodoznawstwu XVII wieku”. Bowiem

życie w przyrodzie nie jest ani epifenomenem dającym się zredukować do mechanicznych układów, ani tajemniczą siłą wlaną, wniesioną do przyrody z zewnątrz przez transcendentnego wobec niej Boga. Sama natura jest życiem, a prawa życia są inherentnymi jej prawami. Życie, stawanie się, organizacja jest właściwością pierwotną i powszechną universum. Kosmos jest jednym wielkim organizmem, samoorganizującym się bytem celowym. Człowiek jako życie sta-

\footnotetext{
9 J. Bentham, Wprowadzenie do zasad moralności i prawodawstwa, Warszawa 1958,
} s. 420 . 
nowi z nim jedność, jest właściwie partykularyzacją organizacji uniwersalnej. Tym samym czuje się zakorzeniony w tak pojmowanym universum $^{10}$.

Słusznie zatem autor tej wypowiedzi R. Panasiuk podkreśla, że „,filozofię przyrody Schellinga odczytać możemy jako propozycję reintegracji człowieka w świat, jako dążenie do przezwyciężenia separacji jego od przyrody i ustanowienie na miejsce utylitarno-eksploatatorskiego do niej stosunku, estetycznej kontemplacji i bezpośredniego jej przeżywania" ${ }^{11}$. Romantyzm niemiecki w miejsce dychotomicznego podziału na świat ludzki i przyrodniczy zaproponował ideę jedności i wspólnoty, w której to, co ludzkie i naturalne, nie jest sobie przeciwstawne, lecz stanowi jedną harmonijną całość. W tym ujęciu losy ludzkie splatają się z losami przyrody, tak jak było to kiedyś, w odległej przeszłości. Jednocześnie romantycy zdecydowanie przeciwstawiali się instrumentalno-ilościowemu traktowaniu przyrody, które jest tak charakterystyczne dla nowożytnego przyrodoznawstwa. Rozum oraz język logiki, którymi nauki przyrodnicze się posługują, coraz bardziej oddalają człowieka od reszty świata, z którym był on w przeszłości zjednoczony. Jest to sytuacja zgubna dla człowieka i przyrody. Człowiek - twierdzą romantycy - posiada jeszcze szansę odnalezienia zagubionej drogi, która poprowadzić go może do jedności i porozumienia ze światem, ale musi przezwyciężyć to, co w procesie rozwoju kultury i cywilizacji oddzieliło i wyobcowało go z universum. Szkoła romantyków poszukiwała jedności i identyczności tam, gdzie inni kreowali podziały i doszukiwali się różnorodności. W tym sposobie ujmowania relacji człowiek - świat natury doszukać się można antycypacji współczesnego myślenia holistycznego.

O potrzebie przymierza i jedności człowieka z przyrodą pisał także filozof, moralista i poeta amerykański Ralph Waldo Emerson (1803-1882). Podobnie jak romantycy występował z otwartą i radykalna krytyką tak powszechnego w jego czasach przedmiotowo-utylitarnego traktowania przyrody. Jego filozofia głosiła ideę harmonijnej zgodności i współzależności świata przyrodniczego i ludzkiego. Owe światy wzajemnie się przenikają, tworząc swego rodzaju jedność, gdyż istotowo - powiada filozof - nie różnią się one, lecz są tym samym. Tak powszechnie eksponowanemu w literaturze owych czasów obrazowi przyrody, zdominowanej przez groźne i brutalne żywioły, przeciwstawiał Emerson postać przyjaznego człowiekowi świata natury, w którym może się on czuć jak u siebie $w$ domu. Wystarczy, aby człowiek w pełni uświadomił sobie ową głęboką jedność z przyrodą, łą-

${ }^{10}$ R. Panasiuk, Człowiek i przyroda. Antropologiczny sens filozofii przyrody Schellinga, w: tenże, Filozofowanie jako dialog z dziedzictwem kulturowym przeszłości, Toruń 2008, s. 41.

11 Tamże, s. 43. 
czącą go trwałą więzią oraz substancjalnie duchowe z nią pokrewieństwo. Wówczas zmieni się zasadniczo postrzeganie przez człowieka samego siebie i otaczającego go świata, co w konsekwencji sprawi, że traktować on będzie naturalne otoczenie jak swoje domostwo, gniazdo, najbardziej elementarną podstawę. Świat przyrody pojmował Emerson jak żywy samoregulujący się organizm, który przez ciągły ruch zmierza do coraz doskonalszych bytów. Dla Emersona wartościowa jest taka sytuacja, w której człowiek, rezygnując z postawy dominacji, uświadamia sobie swoje pokrewieństwo i substancjalna tożsamość ze wszystkim, co go otacza.

Przeciw nasilającemu się zjawisku demarkacji świata ludzkiego i przyrodniczego z jeszcze większym nasileniem protestowali myśliciele dwudziestego wieku m.in.: G. Santayana, A. Schweitzer, M. Buber, G. Marcel, H.-G. Gadamer. Z taką postawą solidaryzuje się także Max Scheler (1874-1928), akcentując solidarność wszystkich istot żywych, zwłaszcza zaś, gdy oponuje przeciw takim konstrukcjom teoretycznym, które wyodrębniają człowieka wraz z jego duchowością z integralnej struktury życia i kosmo$\mathrm{su}^{12}$. Bliski współczesnemu światopoglądowi ekologicznemu wydaje się schelerowski postulat nauki ,kształtowania w sobie kosmowitalnego odczucia jedności”. „Jeśli - powiada filozof - brakuje tego witalnego odczucia jedności człowieka $\mathrm{z}$ całą naturą, to w pewien sposób zostaje on odseperowany od swej wielkiej wiecznej matki-natury, co sprzeciwia się jego istocie"13. W wypowiedzi filozofa na plan pierwszy wysuwa się idea jedności człowieka z naturą, którą wpisuje w jego pierwotny, istotowy charakter. Z tego punktu widzenia krytycznie ocenia podziały i separacje charakteryzujące współczesność, nawołując do ponownego odkrywania i kształtowania poczucia jedności aż po jego kosmowitalny wymiar.

Duchem humanizmu ekologicznego przepojone są myśli i idee wielkiego moralisty XX wieku Alberta Schweitzera (1875-1965). Swój program moralny nazwał on etyka czci dla życia. Jej adresatem był nie tylko człowiek, ale wszystkie istoty żywe, które etyka ta podnosi do rangi bliźniego. Kto respektuje jej ogólną zasadę, temu bliskie jest pragnienie, aby cudzą wolę życia uszanować na równi z własną wolą życia. Etyka Schweitzera głosiła przekonanie, że we wszelkim działaniu należy się liczyć z cierpieniem nie tylko ludzi, ale także i zwierząt, więcej - uważał, że niszczenie życia i szkodzenie mu jest w każdych okolicznościach złem. Dopiero poprzez uznanie tych zasad dochodzimy do prawdziwego człowieczeństwa. Schweitzer stwierdzał, że tradycyjna etyka, skierowana wyłącznie ku człowiekowi,

12 M. Scheler, Pisma z antropologii filozoficznej i teorii wiedzy, Warszawa 1987, s. 221.

13 Tenże, Istota i formy sympatii, Warszawa 1992, s. 171. 
już nie wystarcza. Potrzebna jest etyka globalna o wiele bardziej elementarna i o wiele bardziej głęboka, która zakresem swej reglamentacji obejmuje świat pozaludzki, wszelkie formy życia. Dla tak pojętej etyki „,dobrem jest utrzymanie życia, popieranie życia, nadawanie najwyższych wartości życiu, zdolnemu do rozwoju; złem - niszczenie życia, szkodzenie życiu, spychanie w dół zdolnego do rozwoju życia"14. Pisząc te słowa, Schweitzer jest w pełni świadomy tego, że dramatyczne konflikty między interesami człowieka a interesami istot pozaludzkich są nie do uniknięcia, że życie jednych istot musi dokonywać się kosztem życia innych, dlatego - podkreśla z naciskiem kiedy szkodzę jakiemuś życiu, muszę zdawać sobie sprawę, że było to konieczne. Każdy bowiem, kto kieruje się etyką czci dla życia, szkodzi życiu tylko z konieczności, której nie może już uniknąć, nigdy zaś z bezmyślności. Respektowanie tej etyki oznacza, że nie wolno bezmyślnie, bez wyraźnej konieczności niczego niszczyć ze świata zwierząt i roślin.

Do innego zasobu argumentacyjnego sięga $\mathrm{w}$ swej filozofii dialogu Martin Buber (1878-1965), uzasadniając potrzebę rozszerzenia osobowej relacji $J a-T y$ również na świat przyrody. W przekonaniu filozofa nawiązanie partnerskiego dialogu człowieka z przyrodą pozwoli ujawnić wiele dotąd niedostrzeganych wartości. Postawa dialogu Bubera ma teologiczne uzasadnienie (związane z tradycją chasydzką). Bóg - powiada Buber - przemawia przez wszystko, co istnieje; odwrócenie się człowieka od świata jest w istocie odwróceniem się od Boga. Materia, cały świat przyrody ożywionej i nieożywionej istnieją po to, aby człowiek obcował z nimi, a poprzez nie obcował z Bogiem. Za pośrednictwem dialogu człowieka ze światem przyrody toczy się dialog człowieka z Bogiem. „Ten, kto naprawdę wychodzi do świata, wychodzi do Boga"15. Wszystko, co istnieje, każde stworzenie, nie jest przeszkodą do Boga, ale drogą prowadzącą ku niemu. W filozofii Bubera postawa egocentryczna, monologiczna, wyrażająca się tylko w Ja i traktująca świat zewnętrzny w kategoriach przedmiotowo-utylitarnych, zostaje zastąpiona postawą dialogiczną, nastawioną na bezpośredni kontakt $\mathrm{z}$ Ty, na życie w obecności innego bytu i w związku z nim.

Wiele formułowanych w dziejach myśli filozoficznej stanowisk, tak jak większość przedstawionych powyżej, zmierzało do rewizji postaw myślowych, hierarchii wartości i koncepcji, które wyznaczały dominujący dotychczas kierunek rozwoju naszej cywilizacji. Nie zdołały się przebić do świadomości ogólnej i nie wywarły znaczącego wpływu na dziejową praktykę ludzką, która kształtowała się wyraźnie pod wpływem antropocentrycznego paradygmatu. Ale łączące je przekonanie, że losy człowieka i przyrody za-

${ }^{14}$ Cyt. za: I. Lazari-Pawłowska, Schweitzer, Warszawa 1976, s. 44.

${ }_{15}$ M. Buber, Ja i Ty, Warszawa 1992, s. 99. 
leżą od tego, czy potrafimy odnaleźć właściwe zasady współistnienia i je realizować, w świetle negatywnych doświadczeń - zwłaszcza ostatnich czasów - nabiera szczególnie wymownych znaczeń.

Być może przetrwamy jako ludzkość - pisze H. G. Gadamer (1900-2002) gdy uda nam się nauczyć, że nie powinniśmy po prostu wykorzystywać środków naszej władzy i możliwości sprawczych, lecz że powinniśmy nauczyć się zatrzymywania przed innymi jako innymi, przed przyrodą tak samo, jak przed dojrzałymi kulturami ludów i krajów i że musimy to, co inne oraz innych doświadczyć tak, jak doświadczamy innych spośród nas samych. Aby uczestniczyć w sobie nawzajem ${ }^{16}$.

\section{Czlowiek - środowisko przyrodnicze w ujęciu ekofilozofii}

Refleksja filozoficzna, odsłaniając dzieje związków człowieka z przyrodą, wyraźnie akcentuje ten fakt, że w europejskim kręgu kulturowym relacja człowiek - przyroda kształtowała się, przynajmniej na przestrzeni ostatnich kilkuset lat, pod wyraźnym wpływem antropocentrycznego paradygmatu. Jego panowanie w świadomości i praktyce społecznej powodowało, że człowiek rozluźniał więzy ze środowiskiem przyrodniczym, którego był organiczną częścią u zarania swego istnienia, aby w sferze mentalnej i z czasem materialnej, izolując się od niego, żyć w stworzonym przez siebie świecie $\mathrm{i}$ ten tylko uważać za wartościowy. To zaś powodowało, że w obszarze praktycznych poczynań coraz częściej stawał wobec swego naturalnego środowiska na pozycji eksploatatora i przeciwnika. Ten sposób myślenia, a w konsekwencji i działania, znajdował swe uzasadnienie w teoriach i poglądach ujawniających się w poszczególnych fazach rozwoju kultury umysłowej nowożytnej cywilizacji europejskiej (paradygmat kartezjańsko-newtonowski).

Towarzysząca wspomnianej dychotomii perspektywa aksjologiczna akcentuje to, że cywilizacja nowożytna nieomal na wszystkich etapach swego rozwoju uczyła szacunku jedynie dla tego, co jest jej wytworem, umacniając $\mathrm{w}$ nas przekonanie o zdecydowanej przewadze świata wykreowanego nad światem zastanym, naturalnym, co w konsekwencji prowadziło do lekceważenia a nawet pogardy dla wszystkiego, co nie jest dziełem człowieka. To, co pierwotne i naturalne, miało być zarazem czymś gorszym, mniej wartościowym od tego, co jest owocem aktywności ludzkiej w sferze produkcyjnej i technicznej, co zarazem jest sztuczne i różne od natury. Innymi słowy człowiek stworzył techno- i antroposferę, którą uznał za nieporównanie lep-

${ }^{16}$ H.-G. Gadamer, Dziedzictwo Europy, Warszawa 1992, s. 23. 
szą, wartościowszą i bliższą sobie od biosfery. Środowisko, które jest wytworem działalności przemysłowo-technicznej, stało się jego środowiskiem. Nastąpiło więc - jak twierdzi Jean Dorst - ,iście schizofreniczne zerwanie między człowiekiem a resztą świata ożywionego lub nieożywionego"17. Alienujący się ze swego naturalnego środowiska człowiek stawał wobec niego na pozycji eksploatatora i przeciwnika. Uznał, że w świat przyrody może interweniować i zmieniać go w sposób nieograniczony, radykalnie i głęboko, nie licząc się z rzeczywistą wydolnością środowiska, z całym niezwykle złożonym zespołem mechanizmów i procesów zabezpieczających jego istnienie i podtrzymywanie. W spadku po nieomal całym rozwoju cywilizacyjnym odziedziczyliśmy przekonanie, że formy życia związane z techniką są bardziej wartościowe i postępowe od form życia przyrodniczego. Wytworzyła się zatem swoista hierarchia wartości przedkładająca dzieło człowieka ponad dzieło przyrody, wzmocniona niesionym przez cywilizację technokratycznym modelem rozwoju, który prowadził do instrumentalnego i utylitarnego traktowania przyrody, jej opanowania i podporządkowania. Między światem ludzkim a światem przyrody, między kulturą i naturą pojawiła się grubo zarysowana linia demarkacyjna.

W świetle wiedzy dostarczanej przez nauki przyrodnicze, jak i w obliczu wielu widocznych już gołym okiem doświadczanych zagrożeń i zjawisk kryzysowych wiemy, że paradygmat nieograniczonej dominacji człowieka nad przyrodą obarczony jest wieloma słabościami. Postępująca degradacja świata przyrodniczego i tym samym warunków życia człowieka są wymownym świadectwem tego, że jego relacja z przyrodniczym otoczeniem nie rozwija się w kierunku symbiotycznej harmonii, lecz jest jej wyraźnym zaprzeczeniem. Coraz lepiej zdajemy sobie sprawę z tego, że nie można tworzyć świata ludzi, który znajdowałby się w konflikcie ze światem przyrody. Słusznie zwracał uwagę na to Ervin Laszlo, gdy stwierdzał: „budujemy sobie najróżnorodniejsze światy, lecz wszystkie one respektować jednak muszą hierarchiczną strukturę ziemskiej przyrody. Zbudowanie świata wykraczającego poza tę granicę stanowiłoby bezpośrednie zagrożenie dla nas samych"18. Jeśli zniszczymy przyrodę - pisała przed kilkudziesięciu już laty Margaret Mead - upadną nasze społeczeństwa. Wielce interesujące przekonanie, choć odwołujące się do innego jeszcze zasobu argumentacyjnego, napotykamy we fragmencie encykliki Jana Pawła II zatytułowanej Centessimus annus (1 maja 1991), poświęconej także zagadnieniom ekologicznym. Czytamy tam: ,u podstaw bezmyślnego niszczenia środowiska naturalnego tkwi błąd antropologiczny, niestety rozpowszechniony w naszych czasach

17 J. Dorst, Sita życia, Warszawa 1987, s. 91.

${ }^{18}$ E. Laszlo, Systemowy obraz świata, Warszawa 1978, s. 139. 
[...] Człowiek mniema, że samowolnie może rozporządzać ziemią, podporządkowując ją bezwzględnie własnej woli [...] w końcu prowokując bunt natury, raczej przez niego tyranizowanej niż rządzonej”. Wyraźnie już dziś dostrzeganym, nie tylko przez ludzi nauki, przykładem owego buntu natury jest proces globalnego ocieplania. Budzi on autentyczny niepokój wybitnych osobistości, uczonych, jak i zainteresowanych tym problemem zwykłych ludzi. O niekorzystnych zmianach klimatu z wielkim zatroskaniem wyrażał się ostatnio Benedykt XVI apelując do polityków i naukowców, aby stawili czoła temu wielkiemu wyzwaniu.

Kryzys środowiskowy, także zacytowane powyżej, pełne niepokoju wypowiedzi dowodzą, że naglącym imperatywem człowieka współczesnego i patrzącego w przyszłość jest odnalezienie drogi ku przyrodzie, która - dewastowana i grabiona - ginie na naszych oczach. Wskazując na to, co różni nas od innych istot zamieszkujących naszą planetę, nie sposób nie zauważyć, że Homo sapiens jest jedynym gatunkiem na Ziemi, który niszczy własne środowisko. Instrumentalny i utylitarny stosunek do przyrody dominuje, w przeważającej mierze, w jego myśleniu i działaniu, a koncepcja podporządkowania i ujarzmiania przyrody jak dotąd wychodziła zwycięsko, przynajmniej w naszym kręgu cywilizacyjno-kulturowym, w starciu z ideą optującą na rzecz związków i kooperacji człowieka $\mathrm{z}$ otaczającym go środowiskiem przyrodniczym. $Z$ powyższym, kluczowym dla teraźniejszych i przyszłości losów człowieka i przyrody problemem pragnie zmierzyć się refleksja ekofilozoficzna. W świetle doświadczanego już kryzysu środowiskowego jej doniosłości i znaczenia nie sposób zakwestionować. Przede wszystkim w oparciu o wiedzę dostarczaną przez nauki przyrodnicze i własną refleksję dyktowaną wymogami myślenia naukowego ekofilozofia pragnie rzetelnie rozpoznać podstawowe zasady powiązań, interakcji i organizacji struktur biologicznych, aby w rezultacie ujawnić najistotniejsze mechanizmy determinujące funkcjonowanie biosfery. Ich rozpoznanie jest warunkiem rzetelnego opisu możliwych związków człowieka z przyrodą oraz właściwego określenia miejsca człowieka w świecie przyrody. Uzyskana wiedza nabiera szczególnie doniosłego znaczenia w kontekście doświadczanych w naszych czasach zjawisk kryzysowych, zwłaszcza gwałtownie przybierającej na sile destrukcji świata przyrodniczego, prowadzącej wprost do katastrofy ekologicznej, zagrażającej dalszemu istnieniu życia w przyrodzie. Ekofilozofia nie poprzestaje na analizie tych wysoce niepokojących zjawisk i procesów, odsłanianiu ich istoty i przyczyn, lecz poszukuje także sposobów przezwyciężania zjawisk kryzysowych i, co niezmiernie ważne, kreuje takie modele rozwoju, które uwzględniałby zarówno interesy i potrzeby człowieka, jak i respektowały warunki życia i rozwoju naturalnych ekosystemów oraz całej biosfery. Szczególną wagę przywiązuje do uzasadnienia sposobów myślenia 
i reguł działania w celu podtrzymania, zachowania i ochrony takiego stanu środowiska, aby był on korzystny dla świata ludzkiego i przyrodniczego.

Rzec więc można, że ekofilozofia pragnie spełniać dwie podstawowe funkcje: teoretyczną i praktyczną. Pierwsza związana jest z procesem poznawania, druga działania. Ten elementarny fakt akcentują wszystkie formułowane przez znawców problematyki definicje ekofilozofii. Autorem jednej z nich jest Andrzej Papuziński, który jest zdania, że ,filozofia ekologii to dział filozofii podejmujący problemy szeroko rozumianej ochrony środowiska przyrodniczego, miejsca człowieka w uniwersum i zależności pomiędzy oddziaływaniem człowieka na przyrodę i jej zwrotnym oddziaływaniem na jakość życia ludzkiego"19.

Zbigniew Hull określa ekofilozofię jako „dziedzinę refleksji filozoficznej”, która „docieka istoty więzi człowieka (społeczeństwa) z przyrodą” i ,zmierza do pożądanego ich kształtowania w zgodzie z przeżywanym dzisiaj doświadczeniem świata i przyjętą hierarchią wartości" ${ }^{20}$. W jednej z najnowszych wypowiedzi Z. Hull rozwija tę myśl, wskazując dodatkowo, że ekofilozofia jest

nową próbą przemyślenia i zrozumienia miejsca człowieka w przyrodzie i ulokowania ludzkiego doświadczenia przyrody w kontekście i strukturze bytowej rzeczywistości, jego ontologicznej i aksjologicznej charakterystyki a także ich odniesienia do sfery społecznej i mentalnej. [...] Jest także epistemologia krytyczna, oceniającą wartość i przydatność metodologii naukowej oraz wszelkich innych rodzajów poznania dla uzyskania życiowo (praktycznie) niezbędnej i poznawczo płodnej wiedzy o interakcjach człowieka ze środowiskiem przyrodniczym i dokonującą wyboru najlepszych (wedle danego autora) metod uzyskiwania takiej wiedzy ${ }^{21}$.

Zdaniem J. M. Dołęgi „ekofilozofia jest nauką filozoficzną o środowisku przyrodniczym i społecznym, czyli o ekosystemie ziemskim i jego otoczeniu z aspektami teoretycznymi i praktycznymi" 22 . Autor tej definicji doprecyzowuje ją poprzez wymienienie kilkunastu jej możliwych ujęć.

19 A. Papuziński, Życie - nauka - ekologia. Prolegomena do kulturalistycznej filozofii ekologii, Bydgoszcz 1998, s. 5.

${ }^{20}$ Z. Hull, Problemy filozofii ekologii, w: A. Papuziński (red.), Wprowadzenie do filozoficznych problemów ekologii, Bydgoszcz 1999, s. 80.

${ }^{21}$ Tenże, Czym jest a czym nie jest ekofilozofia?, w: J. Czartoszewski (red.), dz. cyt., s. 140 .

${ }^{22}$ J. M. Dołęga, Ekofilozofia - nauka XXI wieku, „Problemy ekofilozofii. Studia filozoficzno-sozologiczne" 1 (2006), s. 18. 
W definicjach tych, także w ich kolejnych rozwinięciach i dopełnieniach, autorzy wspólnie wskazują na 1. przynależność nowej dziedziny refleksji do rodziny dyscyplin filozoficznych; 2 . jej mocne oparcie w wiedzy przyrodniczej zintegrowanej z refleksją filozoficzną; 3. potrzebę określenia miejsca człowieka w świecie przyrody wraz z reinterpretacją dotychczasowych poglądów na powyższy temat; 4. próby określenia pożądanych związków świata ludzkiego ze światem przyrody; 5. wykorzystanie osiągniętej wiedzy w praktycznych poczynaniach i działaniach człowieka w środowisku.

Ekofilozofia, poszukując sposobów naprawy zniszczonych relacji między światem ludzkim a środowiskiem przyrodniczym, przekonuje, że warunkiem przetrwania obu tych światów jest budowa harmonii między nimi, gdyż rzeczywistość wraz z istniejącym w niej człowiekiem jest współzależna $\mathrm{z}$ nim egzystencjalnie i funkcjonalnie. W sferze praktycznej idea współzależnego traktowania świata ludzkiego i przyrodniczego nazbyt często występuje jeszcze w postaci zadania. Pierwszym i nieodzownym warunkiem jej urzeczywistniania jest przestrzeganie postulatu, aby rozwój gospodarczy i techniczny w skali lokalnej i globalnej nie destabilizował równowagi ekologicznej, lecz był dostosowany do wydolności środowiska w jego ograniczonym przestrzennie, jak i całościowym wymiarze.

Konieczny wydaje się powrót do mądrej, sformułowanej jeszcze w czasach antycznych zasady umiaru i rozsądku, której sentencjonalny charakter określały reguły: nie przesadzaj w niczem oraz ne quid nimis - nic w nadmiarze. Idzie tu nie tylko o pohamowanie apetytów konsumpcyjnych i rezygnację z jakże destrukcyjnej dla środowiska zachłanności w zaspokajaniu potrzeb. Równie pilną i konieczną staje się potrzeba przemyślenia i zrewidowania idei nieograniczonego wzrostu gospodarczego i zastąpienia jej programem zrównoważonego rozwoju, który brałby pod uwagę ograniczoną ilość nieodnawialnych surowców oraz ograniczoną odporność środowiska na ingerencję technologiczną i gospodarczą człowieka. Tymczasem w wyniku nadmiernego i tym samym niebezpiecznego nadużywania władzy technologicznej i przemysłowej człowiek nie tylko niszczy środowisko, w którym bytuje, ale również - o czym niekiedy zapominamy - zagraża sam sobie. Mówiąc inaczej, degradacja środowiska jest w jakimś sensie także degradacją człowieka. Degradacji ulega biologiczna przestrzeń dla zdrowia i życia człowieka, ale także dokonuje się destrukcja tych aspektów jego etycznych i estetycznych zdolności i wrażliwości, które pozwalają na kształtowanie postawy poszanowania dla wartości otaczającego środowiska i piękna przyrody.

Ekofilozofia, akcentując związek świata ludzkiego i przyrodniczego, opowiada się za ochroną interesów i zabezpieczeniem warunków rozwoju dla obu tych światów. Dlatego tak wyraźnie formułuje i wytycza dwa inte- 
gralnie powiązane ze sobą zasadnicze cele, to jest: obronę świata przyrodniczego przed ludzką agresją i działaniami destrukcyjnymi z jednej strony, z drugiej - obronę człowieka jako jednostki i gatunku przed powodowanym przez niego samego zagrożeniem ekologicznym. Przekonuje, nawiązując do antropocentrycznie zorientowanej argumentacji, że w imię także własnego bezpieczeństwa musimy wypracować racjonalny, zorientowany wartościami humanistycznymi model rozwoju proekologicznego. Powinien on dać odpowiedź na kluczowe pytanie, w jakim zakresie i rozmiarach ludzkość w ujęciu globalnym, a w wymiarach lokalnych określone społeczności, mogą wykorzystywać środowisko przyrodnicze, jakie zaś okoliczności i uwarunkowania wyznaczać powinny granicę nieprzekraczalną dla naszych konsumpcyjnych i eksploatatorskich apetytów. To wielkie zadanie, z którym powinny zmierzyć się konstruowane programy ekorozwoju i zrównoważonego rozwoju. Jest sprawą oczywistą, że skierowane na realizację tego zadania propozycje powinny być przede wszystkim oparte na rzetelnej wiedzy, która uczy, na czym polega równowaga ekologiczna między człowiekiem konsumentem a przyrodniczym środowiskiem, w którym on bytuje i z którego czerpie środki do życia i rozwoju. Ale potrzebna jest także filozofia, która uzmysławia człowiekowi jego naturalne miejsce w świecie i w łańcuchu życia oraz proponuje aksjologię, która odwołując się do określonego systemu wartości odpowiada na pytanie, jak powinien zachować się człowiek wobec swego przyrodniczego otoczenia i dlaczego powinien tak postępować. Filozofia ta powinna dostarczać argumentów mobilizujących do przeciwstawiania się wyłącznie instrumentalnemu i utylitarnemu traktowaniu przyrody a jednocześnie wspomagających proces budowania ogólnobiologicznej wspólnoty, pokojowej koegzystencji antroposfery i biosfery uznając, że - jak powiada L. Herber - ,pogodzenie się świata człowieka z przyrodą nie jest już czymś pożądanym lecz stało się koniecznością"23.

To, co obecnie jawi się jako wyraźny postulat a nawet konieczność, pojawiało się w postaci wstępnych przeświadczeń i intuicji, może nie dość jednoznacznie artykułowanych w wypowiedziach niektórych filozofów już dziewiętnastego i, z nieporównanie znaczniejszą intensywnością, dwudziestego wieku. Śledząc procesy cywilizacyjne, dokonywali oni krytycznej oceny tych poglądów, które uzasadniały zarysowujący się coraz wyraźniej dychotomiczny podział, w ramach którego człowiek, kierując się swoistym antropocentryzmem, zakreślał coraz wyraźniejszą linię demarkacyjną między sobą a przyrodą. To, że podział na świat człowieczy i świat przyrody jest podziałem błędnym, ze szczególną mocą akcentują reprezentanci myśli ekofilozoficznej.

${ }^{23}$ L. Herber, Our Sytethetic Environment, London 1963, s. 14. 
Pionierską dla filozofii ekologicznej rolę spełniła głośna książka Aldo Leopolda A Sand Couty Almanac (udostępniona ostatnio polskiemu czytelnikowi pod zmienionym tytułem Zapiski z Piaszczystej Krainy - 2004). Autor odrzuca przekonanie o wyłącznie służebnej roli przyrody wobec gatunku ludzkiego i nie akceptuje utylitaryzmu, ponieważ naturze nadaje on wartość tylko w takim stopniu, w jakim warunkuje ona ludzką pomyślność i korzyść. Głosił natomiast pogląd, że interesy istot pozaludzkich powinny być brane pod uwagę ze względu na nie same, a nie jedynie wówczas, gdy służą ludzkim celom i potrzebom. Przyroda zaś powinna być uważana za dobro etyczne i przedmiot zobowiązań człowieka. Dlatego zaproponowana przez niego etyka Ziemi (Land ethic) poszerza granice biotycznej wspólnoty, obejmując nią człowieka, świat istot pozaludzkich i Ziemię. Wykracza poza zakres przedmiotowy tradycyjnej etyki, zmierza do rozszerzenia obszaru moralności i ogarnięcia nią sfery relacji człowieka ze światem przyrodniczym. Proponuje nowe myślenie, które w punkcie wyjścia stawia pytanie nie tylko o to, „,co dogodne z gospodarczego punktu widzenia, ale także co jest etycznie i estetycznie słuszne"24. Właściwą odpowiedź Aldo Leopold opiera na przekonaniu, że słuszne jest to, co sprzyja zachowaniu spójności, stabilności i piękna wspólnoty biotycznej. Niesłuszne zaś jest to, co temu nie sprzyja. Leopold krytykuje system ochrony przyrody oparty wyłącznie na korzyściach gospodarczych, gdyż ignoruje on wiele elementów wspólnoty ziemi, zwłaszcza tych, które nie posiadają walorów utylitarnych, za to są niezbędne dla jej zdrowego funkcjonowania. Tu właśnie etyka spełnia niezwykle doniosłą rolę, gdyż nakłada na nas etyczne zobowiązanie ochrony wszystkich bez wyjątku części składowych wspólnoty biotycznej.

Następca i kontynuator Aldo Leopolda, filozof akademicki J. Baird Callicot, twórczo rozwijał myśl autora etyki Ziemi, dając filozoficzne podstawy zorientowanej holistycznie filozofii ekologicznej. Niekwestionowanym osiągnięciem Callicota jest idea etyki wspólnot, jej opracowanie i teoretyczne uzasadnienie, a także koncepcja nowego myślenia określanego mianem paradygmatu ekocentrycznego. Autor etyki wspólnot dzięki profesjonalnemu przygotowaniu zdołał uniknąc tych błędów i uchybień, które wytykano jego poprzednikowi (błąd naturalistyczny). Callicot sformułował filozoficzne podstawy zorientowanej holistycznie filozofii ekologicznej. Etyka holistyczna w przekonaniu tego filozofa nakłada na nas nie tylko określone zobowiązania wobec Ziemi, ale wymaga poświęcenia dla jej dobra, analogicznie, jak przyjmujemy na siebie zobowiązania, łączone często z wyrzeczeniami, wobec rodziny, przyjaciół, kraju. Przy czym etyka ta koncentruje uwagę

${ }^{24}$ A. Leopold, Zapiski z Piaszczystej Krainy (A Sand County Almanac), Bielsko-Biała 2004, s. 276. 
przede wszystkim na wartościach i prawach całych gatunków i naturalnych ekosystemów, zaś poszczególne organizmy indywidualne są tu przedmiotem zainteresowania głównie ze względu na ich funkcjonowanie w określonej wspólnocie biotopowej. Każdy członek wspólnoty biotopowej zasługuje na respekt, gdyż każdy z nich funkcjonuje zgodnie z ewolucyjnie ukształtowaną naturą i przyczynia się do zachowania i ochrony integralności, stabilności i piękna wspólnoty.

Poglądy Callicota stały się bezpośrednią inspiracją dla jednego z najwybitniejszych reprezentantów holistycznej filozofii ekologicznej - Holmsa Rolstona III. Występuje on z propozycją oparcia relacji człowiek - przyroda na kategorii odpowiedzialności oraz analizuje wartości występujące w przyrodzie. Przekonuje, że działanie na rzecz ich optymalizacji wydatnie pomaga człowiekowi w jego harmonijnym współżyciu z naturą. Paul W. Taylor jest twórcą biocentrycznie zorientowanej etyki środowiskowej, nazwanej etyka szacunku dla natury (Respect for Nature). Zdaniem jej autora, postawa szacunku dla natury wynikać ma z przekonania, że każdy organizm, populacja i wspólnota żywych istot, posiada własne dobro (pomyślność) i wewnętrzną wartość. Jeśli powiadamy, że istota ma wewnętrzną wartość, to oznacza, że jej dobro zasługuje na bycie przedmiotem refleksji podmiotów moralnych, a także, że realizacja jej dobra ma wewnętrzną wartość jako wynikająca sama z siebie, z jej powodu. Z kolei Arne Naess, znawca Spinozy i twórca głębokiej ekologii, wskazywał, że istotą myślenia ekologicznego jest stawianie pogłębionych pytań o to ,jakie społeczeństwo, jaki system wychowania, jakie religie są najbardziej korzystne dla życia na tej planecie jako całości" ${ }^{25}$. Wraz z innymi reprezentantami tego nurtu poddawał zdecydowanej krytyce antropocentryzm i mechanistyczny światopogląd, upatrując w nich ideowe przyczyny kryzysu ekologicznego. Domagał się głębokiej i radykalnej zmiany świadomości społeczeństwa. U podstaw owej zmiany powinno znajdować się przekonanie, że „formy życia nie tworzą piramidy z naszym gatunkiem na wierzchołku, a raczej krąg, w którym wszystko jest ze wszystkim powiązane"26.

W tym skrótowym zaledwie wyliczeniu głównych reprezentantów i nurtów filozofii ekologicznej nie może zabraknąć wzmianki o poglądach Henryka Skolimowskiego. Wychodzi on od krytyki paradygmatu mechanistycznego i filozofii pozytywistycznej, które dają jednostronną interpretację rzeczywistości wraz z jej instrumentalnym traktowaniem świata przyrody, w zamian proponuje wizję holistyczną, integrującą, leczniczą, która daje perspektywę całościową i jest innym odczytaniem rzeczywistości i innym

25 B. Devall, G. Session, Ekologia głęboka, Warszawa 1994, s.104.

${ }^{26}$ J. Seed, J. Macy, P. Fleming, A. Naess, Myśląc jak góra, Warszawa 1992, s. 18. 
sposobem odczytania człowieka w całym planie natury. Jeśli pragniemy zawrzeć pokój z Ziemią, to przede wszystkim musimy zmienić dominującą dziś świadomość, która jest zaborczą, pasożytniczą i materialistyczną, na świadomość ekologiczną, która jest rewerencyjną, współodczuwającą i współuczestniczącą w misterium życia. U podstaw kosmologii i świadomości leży założenie, że świat jest sanktuarium. W świecie pojmowanym jako sanktuarium przypada nam rola kustoszy i spolegliwych opiekunów, kierujących się w swym postępowaniu szacunkiem i miłością do całego życia i środowiska, odrzucających idee panowania i dominacji.

W przekonaniu filozofa dotychczasowy sposób myślenia zdominowany był przez postrzeganie świata w perspektywie ekonomicznej, chodzi zaś o widzenie otaczającej nas rzeczywistości przez okulary ekologiczne. Jako podstawowa jawi się potrzeba uznania ekologicznego wymiaru rzeczywistości, gdyż wraz z nim rodzi się człowiek ekologiczny, wrażliwość ekologiczna, rozum ekologiczny, a także świadomość i wartości ekologiczne. Dziś myśleć dobrze - powiada Skolimowski - to myśleć ekologicznie. Dotyczy to myślenia technicznego, politycznego, a nawet religijnego. Dlatego filozofia ekologiczna ,jest nową matrycą nowego rozumienia kosmosu i właściwego współdziałania z naturą i całym światem”27. Jest „filozofią życiodajną”, ponieważ pomaga realizować najgłębsze potencje tkwiące w człowieku, w życiu, ewolucji. Wskazuje również na pilną potrzebę stworzenia alternatywnego stylu życia, który powinien oznaczać zmiany nie tylko w naszej technologii, ekonomii i wzorach życia, lecz zmiany w naszej moralności, racjonalności i pojęciowym myśleniu ${ }^{28}$.

Podkreślić należy, że o ile myśl filozoficzna ma raczej wymiar retrospektywny, to refleksja ekofilozoficzna ma głównie charakter prospektywny. W oparciu o wiedzę przyrodniczą i wyniki dociekań różnych dyscyplin humanistyczno-społecznych zdąża do określenia nowego sposobu myślenia o miejscu człowieka w przyrodzie i jego relacjach z przyrodą, z głęboką nadzieją, że posłuży on do wypracowania scenariusza przyszłości, nowej filozofii rozwoju. Przekonanie to nabiera już dziś bardzo realne wymiary, wszak rezultaty dociekań ekofilozoficznych stanowią istotną część składową tak praktycznie zorientowanych koncepcji rozwoju globalnego, jakimi są zarówno idea ekorozwoju, jak i trwałego i zrównoważonego rozwoju. Nowe filozoficzne myślenie o człowieku i przyrodzie, o ich wzajemnych związkach, wychodzi od rewizji tych sposobów myślenia, hierarchii wartości i koncepcji, które wyznaczały dotychczasowy kierunek rozwoju naszej

${ }^{27}$ H. Skolimowski - wystąpienie - patrz: Materiały z inauguracji Katedry Filozofii Ekologiczznej, z 13 marca 1992, wyd. Politechnika Łódzka, s. 22.

${ }^{28}$ H. Skolimowski, Eco-Philosophy. New Tactics for Living, New York 1981, s. 78. 
cywilizacji. Refleksja ekofilozoficzna krytycznie ocenia obecny, obarczony błędami, model rozwoju cywilizacji. W perspektywie historiozoficznej dokonuje ich wnikliwej analizy, aby na ich tle określić i wyeksponować zwrot, jaki w sposobie widzenia człowieka i świata sama proponuje.

W świetle powyższych rozważań warto zauważyć, że pytanie o stosunek człowieka do przyrody jest $\mathrm{w}$ istocie pytaniem o nową filozofię rozwoju i życia, a więc o taki kierunek przeobrażeń, który uwzględnia zarówno potrzeby i dobro człowieka, jak również interesy i dobro pozaludzkich istot żywych oraz całych ekosystemów, w efekcie pytaniem o taki model cywilizacji, który zabezpieczałby harmonijną koegzystencję świata ludzkiego ze światem biosfery.

\section{Man-Nature Relation in the Light of Selected Philosophical and Ecophilosophical Standpoints (Summary)}

Within the scope of this presentation I would like to present two perspectives of the outlook and analysis of a relation between man and nature: the philosophical and ecophilosophical one. I want to present differences and similarities between them, concerning both the man's place in nature and our attitude toward nature. Within the sphere of European culture the man-nature relation has gained various interpretations. In the reflective horizon of different eras both the paradigms of an instrumental attitude towards nature (anthropocentric paradigm) as well as those of noninstrumental approaches are supported. The latter constitute the philosophical origins of pro-ecological thinking, developed further by eco-philosophy, which takes effort to build up both, the theory and practical counter-measures aimed at overcoming the ecological crisis. 